\title{
The Integrated Supervision of Financial Markets: The Case of Switzerland
}

\author{
Philippe Gugler \\ Université de Fribourg, Fribourg, Switzerland. \\ E-mail: philippe.gugler@unifr.ch
}

Sound financial markets are of tremendous importance to the functioning of a national economy. Regulation and supervision are essential not only in order to maintain the financial markets' stability and integrity, but also to protect the interests of depositors, investors, consumers, and insurance policyholders and ensure the proper functioning of business transactions. In order to monitor effectively the current developments of financial markets, it is essential to review and adjust periodically regulation and supervision mechanisms.

The Geneva Papers (2005) 30, 128-143. doi:10.1057/palgrave.gpp.2510001

Keywords: financial market supervision; regulation; integrated market surveillance; Swiss financial system; supervisory authority

A heated debate on the advantages and disadvantages of adopting an integrated financial services supervision system has been taking place in recent years. ${ }^{1}$ This debate has ensued for several reasons, including: the rapid structural changes that have taken place in financial markets spurred by the acceleration in financial innovation; the observation that, historically, financial structures have resulted from a series of $a d$ hoc and pragmatic policy initiatives raising the question of whether a more coherent structure should be put into place; the increasing complexity of financial business as evidenced by the emergence of financial conglomerates; the increasing demand on enhanced regulation of "conduct of business" such as the covering of financial products such as pension schemes; the changing risk characteristics of financial firms due to financial innovation; and the increasing internationalization of financial service providers, which has implications for the institutional structure of agencies at both the national and international level. ${ }^{2}$

Much attention has been focused on whether or not to introduce an integrated supervision because of the key role of financial markets in the Swiss economy. An assessment of the Swiss financial system has shown that it faces challenges because of, inter alia, the increasing international integration of global finance and the rapid pace of technological change. ${ }^{3}$ In addition, Switzerland still has to overcome problems of perception and image with regard to its efforts to combat abuses in its financial system. ${ }^{4}$

This paper, which will examine the supervision of financial markets in Switzerland, is divided into two parts. The first part will focus on the current regulation of financial

\footnotetext{
${ }^{1}$ Martinez and Rose (2003).

2 Taylor and Fleming (1999, p. 3); Goodhart et al. (1998).

${ }^{3}$ Federal Department of Finance (2003).

${ }^{4}$ Ibid.
} 
markets in Switzerland and will examine the organization, tasks, funding, and independence of the different supervisory authorities. The weaknesses of this institutional supervisory system will then be put forward. The second part will discuss the question of an integrated supervisory authority. This will be done in three steps. First, the main foreign experiences regarding integrated supervision of financial markets will be examined. Then the works of the relevant expert commissions in Switzerland will be presented. Finally, the new steps for the establishment of a genuine supervisory authority will be explained.

\section{Current supervision of financial markets in Switzerland}

Financial market supervision aims to act in the general interest of the Swiss economy by guaranteeing a stable financial centre, maintaining confidence and reputation, as well as protecting depositors and investors. Currently, financial market supervision in Switzerland is based on the institutional model. In other words, regulation and rules are specific to each type of institution, and therefore organized into the following separate authorities: the Swiss Federal Banking Commission (SFBC), the Federal Office of Private Insurance (FOPI), the Money Laundering Control Authority (MLCA), and the Swiss Federal Gaming Board (SFGB). It shall be demonstrated, however, that this system is rather inefficient with regard to institutional surveillance, non-regulated financial service providers, independence of existing supervisory authorities, and the sanctions regime.

\section{Supervisory authorities}

In this section, the tasks, regulation, financing, and degree of independence of the different organizations outlined above will be examined.

\section{The Swiss Federal Banking Commission}

The $\mathrm{SFBC}^{5}$ is a standard supervisory authority of the Confederation. On the administrative level, it is integrated into the Swiss Federal Department of Finance. However, it is not part of Central Government Administration. Its organization is provided for in the SFBC Act of 20 November 1997. The Commission is composed of seven to nine members who are appointed by the Federal Council on the basis of criteria designed to guarantee their independence. A permanent secretary prepares cases, makes suggestions, and executes the decisions of the Commission. In some cases, the secretary may also take minor decisions.

The Banking Commission has been responsible for the supervision of the banking sector since 1934. In time, its activities have extended to broader areas of the financial sector. At present, it is responsible for the supervision of banks, investment funds, the mortgage bond business, stock exchanges and securities dealers, as well as the disclosure of shareholdings and public takeover bids. The Commission is designed

\footnotetext{
${ }^{5}$ SFBC Internet site: www.ebk.admin.ch
} 
inter alia to protect creditors and investors and to guarantee the functionality of securities. The Commission funds its activities by collecting an annual supervisory fee, which is charged to persons and institutions subject to its supervision on the basis of the costs incurred in the previous year (ordinance on the perception of taxes and emoluments). The Commission is therefore financed independently from the Confederation's finance budget (according to the principle of covering costs).

Supervision is based on a "two-tiered" system. ${ }^{6}$ Private authorized audit firms monitor prudential rules and other aspects of supervision (such as measures for the prevention of money laundering, internal organization of banks, and respect of legal conditions of authorization). The Commission then verifies that institutions subject to supervision respect regulations on the basis of a detailed report established by these audit firms.

However, this system is sometimes questioned. On the one hand, private firms conducting audits are hired by the institutions subject to supervision. They may therefore be subject to pressure. On the other hand, they compete with other audit firms, and are therefore pushed to achieve minimal costs, which may imply minimal control. $^{7}$ Examples illustrating the weaknesses of the control of auditing activities include the revision of the Banque Cantonale Vaudoise ${ }^{8}$ and that of the Globo Bank. ${ }^{9}$

In order to improve its two-tiered system, the SFBC decided to introduce new measures. ${ }^{10}$ These included the creation of a unit whose task is inter alia to control analysis procedures of audit firms, and in the long term, the development of benchmarks that are imposed on all revisers.

As far as punishment measures are concerned, the SFBC's sanctioning tools are of a preventive character. Although the SFBC may revoke an institution's licence or remove individuals from a company, the measures at its disposal remain limited. ${ }^{11}$

\section{Federal Office of Private Insurance}

The FOPI ${ }^{12}$ has a history of more than 100 years. This office is composed of a staff of approximately 60 people. It is divided into four partially autonomous teams that report directly to the management. The office was attached to the Swiss Federal Department of Justice and Police (FDJP) until 1 July 2003. It was then attached to the Federal Department of Finance (FDF). It remains fully part of Switzerland's Central Federal Administration.

The FOPI supervises the activities of private insurance facilities in the following areas: life and health insurance, accident insurance, insurance against damages, and reinsurance. Insurances such as the Old Age and Survivors Insurance, the Swiss National Accident Insurance, and the Swiss Military Insurance are not supervised by

\footnotetext{
${ }^{6}$ Zufferey (2003, p. 1).

${ }^{7}$ Supervision of Financial Markets Expert Group (2000).

${ }^{8}$ SFBC (2002, p. 40f).

${ }^{9}$ Ibid. (p. 39f).

${ }^{10}$ Zufferey (2003, p. 2).

${ }^{11}$ SFBC (2002, p. 17).

${ }^{12}$ FOPI Internet site: www.bpv.admin.ch
} 
the Office. The FOPI also contributes to the development of legislation and international agreements in the private insurance domain.

Insurance firms fully assume the costs linked to their supervision. This is done by collecting annual taxes (according to the ordinance on the perception of emoluments covering the costs of insurance supervision).

\section{Money Laundering Control Authority}

The MLCA $^{13}$ is a division of the Federal Finance Administration (Federal Department of Finance). The Authority is divided into four sections: a section of self-regulating organizations (SROs), financial intermediaries directly subordinated to the Control Authority, an audit section, and a market supervision section. Its management is composed of a director, who is nominated by the Federal Council, his/ her substitute, and section managers.

As the recognition and supervision of SROs are part of its tasks, the MLCA must ensure that the persons and the revision organs responsible for control activities are completely independent of the management and of the financial intermediaries they supervise.

The MLCA monitors the financial intermediaries that are not subject to specific legal regulations, i.e. the service providers that are active in the non-banking sector (independent asset managers, trust companies, foreign exchange dealers, investment funds, and certain activities of lawyers and notaries). ${ }^{14}$ The costs of the Control Authority are covered by the Confederation's general budget, because it is part of the Federal Finance Administration. It also levies emoluments for its services and decisions. The Authority's activities are consequently only partially financed according to the principle of cost covering.

\section{Swiss Federal Gaming Board}

The SFGB is a control authority that is attached to the Federal Department of Justice and Police only on an administrative level. So it is not a part of the Central Federal Administration. The Board is composed of seven members who are selected by the Swiss Federal Council and who must be independent from gaming clubs. The Board also employs a secretary who prepares its affairs, makes proposals, and executes its decisions.

The Gaming Board assures the technical and organizational functioning of gaming clubs and ensures that the Act on Gaming Clubs is respected. The Gaming Board benefits from a considerable amount of independence, as it is linked to the FDJP only on an administrative level.

The different surveillance organs described are summarized in Table 1.

\footnotetext{
${ }^{13}$ MLCA Internet site: www.gwg.admin.ch

${ }^{14}$ Zimmerli Commission (2003, p. 14).
} 
The Geneva Papers on Risk and Insurance Issues and Practice

132

Table 1 Swiss supervisory authorities of financial markets

\begin{tabular}{|c|c|c|}
\hline Authority & Institutions subject to surveillance & Independence \\
\hline SFBC & $\begin{array}{l}\text { Banks, investment funds, mortgage bond } \\
\text { business, stock exchanges and securities } \\
\text { dealers, disclosure of shareholdings and } \\
\text { public takeover bids }\end{array}$ & $\begin{array}{l}\text { Criteria guaranteeing independence: } \\
\text { Attached to the Federal Department of } \\
\text { Finance only from an administrative point of } \\
\text { view. Does not receive orders from public } \\
\text { authority } \\
\text { Members hired by Federal Council on the } \\
\text { basis of criteria guaranteeing independence } \\
\text { Sources of potential problems: } \\
\text { Delegation of tasks to external revision } \\
\text { societies hired by establishments subject to } \\
\text { surveillance }\end{array}$ \\
\hline FOPI & $\begin{array}{l}\text { Private insurance facilities in three areas: } \\
\text { life insurance, insurance against accidents, } \\
\text { and damage reinsurance }\end{array}$ & $\begin{array}{l}\text { Dependent on authorities: } \\
\text { Attached to the Federal Department of } \\
\text { Finance and integrated into the Federal } \\
\text { Administration }\end{array}$ \\
\hline MLCA & $\begin{array}{l}\text { Financial intermediaries that are active in } \\
\text { the non-banking sector and are not } \\
\text { subject to any specific legal regulations }\end{array}$ & $\begin{array}{l}\text { Dependent on authorities: } \\
\text { Division of the Federal Finance } \\
\text { Administration } \\
\text { Sources of potential problems: } \\
\text { Delegation of tasks to SROs }\end{array}$ \\
\hline SFGB & Gaming clubs & $\begin{array}{l}\text { Criteria guaranteeing independence: } \\
\text { Integrated administratively within the Federal } \\
\text { Department of Justice and Police } \\
\text { Members hired by Federal Council on the } \\
\text { basis of criteria guaranteeing independence } \\
\text { Sources of possible potential problems: } \\
\text { External revision societies hired by gaming } \\
\text { clubs }\end{array}$ \\
\hline
\end{tabular}

Insufficient aspects of the system

As stated by Abrams and Taylor, "Maintaining and enhancing supervisory capacity and the effectiveness of supervision should be primary goal of any proposed regulatory reforms. As such the development of regulatory capacity should be given prominence over the issue of regulatory structure, and the latter is only a matter of fundamental concern to the extent that it can assist in achieving this overarching objective. In general, there are a number of general prerequisites which any regulatory structure should meet if it is to have a reasonable likelihood of success". ${ }^{15}$ The main prerequisites are independence, adequate resources, effective enforcement powers, comprehensiveness of regulation, and cost-efficient regulation. Currently, the Swiss

15 Abrams and Taylor (2000, p. 5). 
supervisory system of financial markets is insufficient in several aspects. Indeed, as far as the above-mentioned prerequisites are concerned, there are shortcomings regarding institutional surveillance, non-regulated financial service providers, independence of existing supervisory authorities, and penalty/sanction regime.

\section{Institutional surveillance}

In the case of institutional supervision, as seen above, each sector has its own supervisory organ. Identical operations are regulated by different authorities, depending on what type of institution provides them. For example, banks are supervised by the SFBC, private insurance companies are supervised by the FOPI, gaming clubs are supervised by the SFGB, and non-regulated service providers are supervised by the MLCA. Pension funds are subject to the Swiss Act on Occupational Benefits ${ }^{16}$ and a significant portion of them is supervised by cantonal authorities. Common occupational benefit institutions are supervised by the FOPI or the SFBC, depending on whether they are life insurance firms or banks. As far as asset management is concerned, the supervision of these services depends, as stated, upon the type of service providers, for example, the SFBC for banks or the FOPI for insurance companies, but a supervisory loophole exists in the case where the service provider is an independent asset manager. With regard to life insurance services, for example, those activities are supervised by the SFBC if the service providers are banks and by the FOPI if the service providers are insurance companies.

The disadvantages of this system include: regulatory disparities according to the branches of activity that create distortion in competition in highly competitive markets; also, sectoral regulators may more easily be "captured" by the sector they supervise. ${ }^{17}$

\section{Non-regulated financial service providers}

Some service providers active in the non-banking sector are not subject to any specific regulation and are not supervised (except by the MLCA). These include independent asset managers, foreign exchange dealers, and introducing brokers. Regulation must take into account the specificity of institutions. However, the principle of competition neutrality requires that firms that provide the same services and generate the same risks should be subject to an identical set of rules - same business, same risks, same rules. ${ }^{18}$ For example, while banks' independent asset managers are active in the asset management business, the former are regulated whereas the latter are not supervised for the same activity.

\section{Independence of existing surveillance authorities}

Supervisory authorities should not be influenced by political and/or economic powers. For the moment, Switzerland's authorities are integrated within the Central Federal

\footnotetext{
${ }^{16}$ Loi sur la Prévoyance Professionnelle Vieillesse, Survivants et Invalidité.

${ }^{17}$ Kahn (1971); Posner (1971); Stigler (1971); Buchanan and Tollison (1972); Peltzman (1976).

${ }^{18}$ Supervision of Financial Markets Expert Group (2000, p. 21).
} 
Administration or attached to a federal department on an administrative level. Because of the complexity of tasks, greater autonomy and financial independence would be necessary. ${ }^{19}$

\section{Sanctions}

In its April 2003 report on sanctions, the SFBC declared that the instruments currently at its disposal were insufficient. In effect, the Commission is not able to impose administrative sanctions of a financial nature. Its sanctions merely aim to restore order in the marketplace. ${ }^{20}$ For example, the SFBC may revoke an institution's licence, remove individuals in positions of authority, and issue official reprimands. However, this can be difficult if removal is a disproportionate measure or when directors cannot be removed from their position. ${ }^{21}$ Furthermore, this regime is not severe enough to guarantee effective supervision. In order to solve this problem, the report suggests including financial sanctions in the new law on financial market regulation. These should be applicable to natural persons as well as legal entities ${ }^{22}$ and could reach 5 million Swiss francs for individuals and 50 million Swiss francs for financial establishments. The integrated supervisory authority provided for in the new law should also be able to suspend professional activity by way of administrative ruling.

In its second report, which will be presented later in this paper, ${ }^{23}$ the Zimmerli Commission analysed the various penalty regimes currently used by the different supervisory bodies that are presently in place. It found that the sanction system is not very uniform, which is likely a result of the different laws that were adopted at different points in time. Furthermore, the sanctions were often considered to be too weak.

\section{Towards integrated financial market supervision in Switzerland}

A wide range of arguments has been presented in favour of an integrated financial market supervision. ${ }^{24}$ The most powerful arguments are based on efficiency gains, on the need to revise supervisory coverage in light of the rise of financial conglomerates, and on the need to ensure competitive neutrality in the light of the blurring of distinctions between the various classes of financial institutions. ${ }^{25}$

Arguments against an integrated financial market supervision have been advanced as well, as for example the view that integration will result in unclear objectives for the regulatory agency, that economies of scope will be hard to achieve while diseconomies of scale will occur, and that it will extend moral hazard concerns across the whole financial services sector. ${ }^{26}$

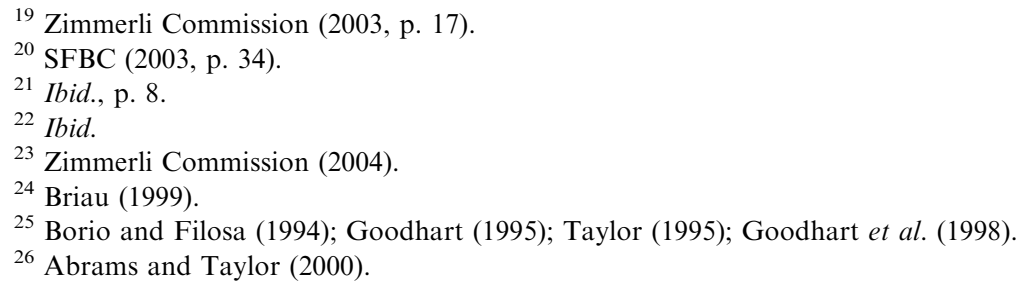


With regard to the different weaknesses of the Swiss regulatory structure mentioned above, the establishment of a new financial market supervisory system could eliminate some of these shortcomings. We have to admit that an integrated supervision system would not be necessary to remove some of the weaknesses identified, such as independence or sanction regime. However, important shortcomings of the Swiss regulatory structure identified by the Zufferey Report ${ }^{27}$ could hardly be removed within a non-integrated regulatory framework (efficient supervision of financial conglomerates, competitive neutrality, regulatory efficiency).

Taking into account the debate in favour of or against the implementation of an integrated supervisory regulation, it is interesting to consider first the situation in other countries where the integrated supervision model has already proved to be successful. Secondly, we will expose the different works that have been carried out in Switzerland in order to modify the current system. Finally, the results of these works will be used to outline the next steps that are currently contemplated in order to create, or not, a fully integrated financial market supervision in Switzerland.

\section{Integrated supervision of financial markets set up abroad}

Questions linked to the principles of prudential supervision and the optimal organization model of this supervision have also been examined in other countries. ${ }^{28}$ Currently, countries are debating on whether supervision should be generalized or specific to each financial sector. At the end of 2002, at least 46 countries had adopted the so-called model of unified or integrated supervision by either establishing a sole supervisor for their entire financial sector or by centralizing in one agency the powers to supervise at least two of their main financial service providers. ${ }^{29}$

In the European Union, prudential control is based on the principle of subsidiarity. Each Member State monitors its financial markets according to its national legislation. ${ }^{30}$ Thus, several organization modes exist. For example, in the United Kingdom, the Financial Services Authority supervises banks, insurance companies, pension funds, and other financial establishments, while in Spain three separate supervisory authorities operate for banks, securities dealers, and insurance.

The following countries decided to integrate their financial markets: Norway in 1986, Canada in 1987, Denmark in 1988, Sweden in 1991, Japan in 2000, Great Britain in 2001, Germany and Austria in 2002, and Ireland in 2003 (see Table 2). Generally, these countries wanted to address the weaknesses of existing supervisory authorities and adapt themselves to market evolution, notably in the field of global finance (different forms of co-operation between financial service providers and other institutions such as banks, insurance companies, etc.). Furthermore, the integration was justified for efficiency reasons as it helps reduce costs, harmonizes rules, and

\footnotetext{
${ }^{27}$ Supervision of Financial Markets Expert Group (2000).

${ }^{28}$ Lubochinsky (2003, p. 4).

${ }^{29}$ Martinez and Rose (2003, p. 5).

${ }^{30}$ Lubochinsky (p. 5).
} 
The Geneva Papers on Risk and Insurance Issues and Practice

136

Table 2 Main countries with an integrated supervisory body

\begin{tabular}{|c|c|c|c|}
\hline Country & $\begin{array}{l}\text { Integrated supervisory } \\
\text { authority }\end{array}$ & $\begin{array}{l}\text { Principal institutions } \\
\text { under supervision }\end{array}$ & Remarks \\
\hline Germany & $\begin{array}{l}\text { Bundesanstalt für } \\
\text { Finanzdienstleistungsaufsicht, } \\
\text { 2002, www.bafin.de }\end{array}$ & $\begin{array}{l}\text { Banks, insurance } \\
\text { companies, securities } \\
\text { dealers }\end{array}$ & $\begin{array}{l}\text { - Several ministries are } \\
\text { represented in the board of } \\
\text { directors } \\
\text { - The authority may issue } \\
\text { fines of up to } 500,000 \text { euros }\end{array}$ \\
\hline Austria & $\begin{array}{l}\text { Finanzmarktaufsicht, } 2002 \text {, } \\
\text { www.fma.gv.at }\end{array}$ & $\begin{array}{l}\text { Banks, insurance } \\
\text { companies }\end{array}$ & $\begin{array}{l}\text { - Independent according to } \\
\text { law } \\
\text { - The FMA will be invested } \\
\text { with administrative criminal } \\
\text { power }\end{array}$ \\
\hline Canada & $\begin{array}{l}\text { Office of the Superintendent } \\
\text { of Financial Institutions, } \\
\text { www.osfi-bsif.gc.ca }\end{array}$ & $\begin{array}{l}\text { Banks, insurance } \\
\text { companies, pension } \\
\text { funds, credit } \\
\text { establishments }\end{array}$ & $\begin{array}{l}\text { - Under the authority of the } \\
\text { Finance Ministry, which } \\
\text { explains its activity to the } \\
\text { Parliament } \\
\text { - Acts independently }\end{array}$ \\
\hline Denmark & $\begin{array}{l}\text { Danish Financial } \\
\text { Supervisory Authority, } \\
\text { 1988, www.ftnet.dk }\end{array}$ & $\begin{array}{l}\text { Banks, insurance } \\
\text { companies, pension } \\
\text { funds, securities dealers }\end{array}$ & $\begin{array}{l}\text { - Attached on an } \\
\text { administrative level to the } \\
\text { Economy Ministry } \\
\text { - Acts independently }\end{array}$ \\
\hline Great Britain & $\begin{array}{l}\text { Financial Services } \\
\text { Authority, 1997, } \\
\text { www.fsa.gov.uk }\end{array}$ & $\begin{array}{l}\text { Banks, insurance firms, } \\
\text { investment firms, } \\
\text { pension funds }\end{array}$ & $\begin{array}{l}\text { - Independent of government } \\
\text { - Reports to the Finance } \\
\text { Ministry and indirectly to } \\
\text { the Parliament. } \\
\text { - Is financed by emoluments } \\
\text { of supervised establishments } \\
\text { - The FSA can apply financial } \\
\text { penalties (from April } 2001 \text { to } \\
\text { April } 2002 \text {, the penalties } \\
\text { amounted to } 5 \text { million } \\
\text { pounds) }\end{array}$ \\
\hline Ireland & $\begin{array}{l}\text { Irish Financial Services } \\
\text { Regulatory Authority, 2003, } \\
\text { www.ifsra.ie }\end{array}$ & All financial sectors & $\begin{array}{l}\text { - Depends on the Finance } \\
\text { Ministry }\end{array}$ \\
\hline Norway & $\begin{array}{l}\text { Kredittilsyinet, 1986, } \\
\text { www.kredittilsynet.no }\end{array}$ & $\begin{array}{l}\text { Banks, insurance } \\
\text { companies, financial } \\
\text { societies, stock markets } \\
\text { and securities dealers }\end{array}$ & $\begin{array}{l}\text { - The Finance Ministry gives } \\
\text { instructions and deals with } \\
\text { appeals or complaints } \\
\text { against the supervisory } \\
\text { authority }\end{array}$ \\
\hline Sweden & $\begin{array}{l}\text { Finansinspektionen, 1991, } \\
\text { www.fi.se }\end{array}$ & $\begin{array}{l}\text { Banks, insurance firms, } \\
\text { investment funds, stock } \\
\text { markets and securities } \\
\text { dealers }\end{array}$ & $\begin{array}{l}\text { - The government chooses the } \\
\text { members of the board of } \\
\text { directors } \\
\text { - Acts independently } \\
\text { - After stock market crises in } \\
\text { recent years, the FI is } \\
\text { directing itself towards the } \\
\text { reinforcement of preventive } \\
\text { identification of risks and is } \\
\text { searching for new methods } \\
\text { of calculating these risks }\end{array}$ \\
\hline
\end{tabular}


creates flexibility in human resources. In addition, there were also reasons specific to each country.

The following developed countries have not integrated their system of supervision yet: Belgium, Finland, France, Greece, Italy, Luxembourg, the Netherlands, Portugal, Spain, the United States, and Switzerland. In Finland, the unique nature of its insurance companies (premiums and conditions set by the government) prevents integration. In Italy, integration would deprive the Bank of Italy of its function as a guarantor of competition. ${ }^{31}$ The complexity and size of the United States financial system requires that it maintain separate and regional supervision. In France, integration failed because of resistance from unions and because the insurance market is characterized by strong government intervention.

\section{Developments in progress in Switzerland}

In 1998, the Swiss Federal Council appointed an experts group (chaired by Professor Zufferey from the University of Fribourg) in order to examine the different challenges that financial market supervision in Switzerland faces (the expert group on financial market supervision). In November 2000, the expert group published its final report, which included 42 recommendations for banks, insurance firms, global finance and financial conglomerates, and for non-regulated financial service providers. It also recommended the organization of overall supervision, ${ }^{32}$ concerning which the expert group recommended the creation of an integrated financial market supervisory authority.

In 2001, the Federal Council appointed an expert commission headed by Professor Zimmerli from the University of Berne (Zimmerli Commission) for the legislative follow-up of the final report of the Zufferey expert group. The mandate of the Zimmerli Commission was to present a legal project that would improve the regulation of financial markets. It should, in particular, elaborate a proposition aiming to establish an integrated supervisory authority of financial markets grouping the activities of the SFBC and the FOPI; examine whether the MLCA and the SFGB should be transferred to the integrated authority; set the status of the integrated body in a law; elaborate a proposition concerning the extension of prudential supervision to introducing brokers, foreign exchange dealers, and independent asset managers; elaborate the legal provisions aiming to differentiate and simplify the regulation of financial markets; examine the instruments of insurance supervision; formulate, if necessary, the legal provisions relative to the objectives of the supervision of global finance and financial conglomerates; elaborate the legal provisions relative to the objectives of financial market supervision and create an article relative to ethics; and finally, examine the sanctions regime. ${ }^{33}$

In July 2003, the Zimmerli Commission published its first partial report, in which it proposed a draft law (LFINMA) dealing with the creation of an integrated

\footnotetext{
${ }^{31}$ Zimmerli Commission (2003, p. 20).

${ }^{32}$ Supervision of Financial Markets Expert Group (2000).

${ }^{33}$ Zimmerli Commission (2003).
} 
authority. ${ }^{34}$ The report suggested the creation of an institution under public law with its own jurisdictional personality. Integration was to be settled gradually. In a first phase, only the SFBC and the FOPI were to be integrated. The commission indicated that additional integration of, on the one hand, supervisory authorities such as the MLCA, and on the other hand, financial institutions (independent asset managers, introducing brokers, etc.) could be carried out later on. The main proposals of the Commission are discussed below. Initially, it would be up to the Federal Council, and then to the Parliament, to accept, adjust, or reject those proposals.

The new body, called the Federal Financial Market Supervisory Authority (FINMA), is to be composed of two main organs: the supervisory board (LFINMA, Article 7, indent 2) and the management board (LFINMA, Article 8). The supervisory board, the FINMA's strategic organ, is composed of seven to nine members with appropriate expertise who are selected by the Federal Council. It defines guidelines and oversees supervisory activity. It also gives the management board advice on fundamental questions. It elects the members of the management board and approves the annual budget, report, and accounts. The influence of the supervisory board should not be underestimated and its independence should be ensured. The management board is composed of the chairpersons of the FINMA's departments and is responsible for the execution of supervisory tasks (it carries out the strategies of the supervisory board). Each FINMA department will cover a specific area such as, for example, an insurance department and a banking department. This structure will avoid any hierarchy among departments and responds adequately to the fear expressed by some specialists that the banking supervisors could take the lead in such a new financial regulatory body. The revision body would control the FINMA's accounting.

As the FINMA incorporates the Banking Commission and the Office of Private Insurance, it will also take over their tasks, that is, the supervision of banks, securities dealers, investment funds, private insurance firms, and the stock market.

The FINMA would be the SFBC's two-tiered system, which means that audit firms will carry out the supervision of institutions. This system poses some problems: the current supervision system is "monist" and plans the externalization of tasks to third parties. ${ }^{35}$ However, Article 32 of the revision project of the insurance supervisory law authorizes the help of third parties in order to ensure that the legal prescriptions are complied with. On the other hand, the weaknesses of banking supervision's two-tier system have already been discussed. Private audit firms are designated by supervised institutions and may be subject to pressure.

Officers' salaries should reflect market rates, according to the recommendations of the International Monetary Fund in its analysis of Switzerland. ${ }^{36}$ As the Swiss Law on the Confederation's staff offers insufficient flexibility, the FINMA's employees will have their own status. ${ }^{37}$

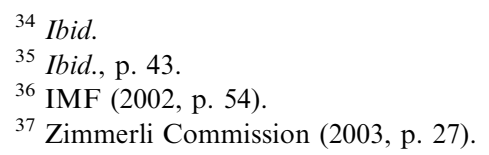


Like the other bodies that execute the Confederation's tasks, the FINMA will be subject to the strong supervision of the Federal Assembly, to which it will present an annual report on its supervisory activities (LFINMA, Article 19). The Federal Assembly must respect the FINMA's independence principle. Control will be limited to the administrative domain and to the allocation of resources. Neither the Federal Council, nor the Federal Assembly may give the FINMA instructions or influence its supervisory activity by any other material means. The costs of supervision are covered by emoluments and taxes levied by the supervised institutions.

The Zimmerli Commission published a second report in August 2004 on the introduction of a new penalty regime. ${ }^{38}$ The instruments of the FINMA should allow it to take pre-emptive and repressive action for the purpose of guaranteeing the smooth functioning of the supervised firms and the market, as well as the protection of creditors, investors, and insured persons. The FINMA must therefore be given the ability to impose sanctions on persons and firms that do not comply with its rules. In the present situation, the supervisory bodies only have limited opportunities to impose sanctions, and the whole sanction system has repeatedly been referred to as inadequate and incomplete by national and international experts. Sanctions may be imposed on the basis of five different laws, depending on the type of firm and the type of behaviour that is involved. Furthermore, self-regulation bodies may also impose sanctions on their members. The sanctions vary substantively between the legal texts, and thus the deterrence effect is rather variable too.

The Zimmerli Commission foresees penal and administrative sanctions. The penal sanctions may take the form of imprisonment for up to three years or monetary fines of up to 1,080,000 CHF for natural persons. Firms may face fines of up to 5,000,000 CHF. They are subsidiarily liable to pay a fine if, for organizational reasons, it is impossible to identify the liable natural person. The new project reduces the number of elements of crime to a number of duties and prohibitions that are considered to be of primary importance in the LFINMA. The administrative sanctions, on the other hand, have been expanded. Besides the ability to withdraw the authorization to exercise a profession, the new project foresees the possibility of banning someone from any profession within the field of supervision.

The Zimmerli Commission found it inadequate that the FINMA act as both the administrative body and the penal body. Therefore, the Commission suggested designating the Federal Department of Finances (FDF) as the body responsible for penal action.

New steps

In a third step, the Zimmerli Commission will examine the possibility of the extension of prudential supervision to independent asset managers, introducing brokers, and foreign exchange dealers, and the integration of other supervisory authorities within the FINMA. The task of the Commission is to propose some options that could be developed further by a specific new working group.

\footnotetext{
${ }^{38}$ Zimmerli Commission (2004)
} 
140

The extension of prudential supervision to independent asset managers, introducing brokers, and foreign exchange dealers would follow the Zufferey Commission's recommendation. However, according to the several opinions expressed during the consultation procedure regarding the first proposal of the Zimmerli Commission, the options are numerous. The two extremes are, on the one hand, to have a total submission of those institutions to the FINMA and on the other hand to let them out of any new regulation.

Foreign exchange dealers could be subject to the FINMA, since the risks they generate are similar to those of securities dealers that are subject to the Securities Act (SESTA). The question of the integration of introducing brokers is complex, because it is not easy to identify and estimate the risks that they generate. However, if one assumes that these risks are real, this issue should be resolved. ${ }^{39}$ The 2000 to 2500 independent asset managers in Switzerland process 10 per cent of all the funds invested in the country. ${ }^{40}$ For the moment, these firms are not subject to any specific regulation (aside from the MLA, which has a goal other than prudential supervision). The Zufferey Commission identified significant risks generated by independent asset managers that were significant. ${ }^{41}$

Several reasons for the regulation of independent asset managers have been exposed. Firsty, regulation should comply with relevant European Community Law in order to make transnational business possible and avoid outsourcing. Secondly, the significant amount of funds managed requires the securing of the quality of services in order to minimize reputation risks, which are also present in the field of money laundering. Thirdly, regulation that meets international standards guarantees the neutrality of competition between independent asset managers and banks, which also manage assets. However, some experts, such as Schem and Lagassé, ${ }^{42}$ have reservations about the regulation of independent asset managers. The most important argument against the subjection of independent asset managers is the cost of regulation, which would cover 2000-2500 additional firms. Some options could be studied to find a solution in between such as a voluntary submission of independent asset managers to the supervisory authority in order to allow them to comply with E.U. regulation.

The Zimmerli Commission did not examine pension funds, because this area was not included in its mandate. However, pension funds are important in terms of financial transactions and potential risks. Pension funds managed approximately 491

${ }^{39}$ Currently, introducing brokers are subject to indirect supervision through the supervision of foreign banks that work with introducing brokers. According to SFBC jurisprudence relating to Article 39 of the Securities Act of 24 March 1995 (SESTA), introducing brokers are not controlled directly. Only foreign banks with whom introducing brokers work are supervised. Therefore, even if the jurisprudence of the SFBC in the area were to be enhanced, foreign banks affiliated to introducing brokers would be subject to authorization, and not the introducing brokers themselves. Moreover, such a solution would imply that introducing brokers who do not work with foreign banks would not be regulated. It would consequently be wiser to provide for the supervision of these institutions by introducing a new article in the SESTA.

${ }^{40}$ Schem and Lagassé (2003).

${ }^{41}$ Supervision of Financial Markets Expert Group (2000).

42 Schem and Lagassé (2003). 
billion Swiss francs in the year $2000,{ }^{43}$ or in other words, more than 15 per cent of all funds managed that year in Switzerland. In addition, because of the stock market situation in the last couple of years, many insurance firms were faced with diminishing assets and the loss of value of their funds. Currently, each Swiss canton designates an authority, which supervises the occupational benefit institutions in its territory, and verifies that it complies with legal prescriptions (LPP, Article 62, Indent 1). The Federal Department of Home Affairs examined the regulation of pension funds ${ }^{44}$ and raised many questions. These institutions are heterogeneous and complex due to their number and the considerable degree of independence allowed in the organization and implementation of occupational benefits. "Simple" institutions are not subject to the same rules as collective and communal institutions, which are supervised by the FOPI. Differences in regulation imply that there is unequal treatment between institutions and between the insured. ${ }^{46}$ Submitting institutions to an identical set of rules and principles would allow the comparison of information on institutions and central supervision, therefore avoiding unequal treatment. However, there is no consensus on how the supervision of pension funds should be organized. ${ }^{47}$

\section{Conclusion}

A competitive, efficient and stable financial centre operating with integrity is in Switzerland's best interest. Therefore, in view of the rate of innovation and the rapid structural changes in the financial sector, regulatory reform in the field of financial services is advisable. The question regarding the adoption of an integrated supervisory system, as recommended by the Zufferey Report, is of great importance.

This article has highlighted the weaknesses in Switzerland's supervision system of financial markets. The current legal bases of supervision are different for each of the fields of activity discussed, and so are the sanctions in cases where the different laws were not complied with. Furthermore, some financial intermediaries are not subject to supervision (introducing brokers, foreign exchange negotiators, and independent asset managers) or are only subject to voluntary self-regulation.

In order to resolve some of these problems, the Zimmerli Commission recommended the creation of an integrated supervisory authority that would take over the tasks of the SFBC and the FOPI. All the advantages that integrated supervision offers could thus be achieved. Integration offers numerous advantages: it subjects all institutions to the same set of rules (same business, same risks, same rules), reduces the distortion of competition, increases efficiency (reduction of administrative costs and wasteful duplication), and simplifies the exchange of information. Furthermore, it should make the reform of the penalty easier.

\footnotetext{
43 Swiss Federal Statistical Office (2002, p. 29).

${ }^{44}$ Federal Department of Home Affairs (2003).

${ }^{45}$ Beck et al. (2003, p. 5).

${ }^{46}$ Ibid., p. 52.

${ }^{47}$ Federal Department of Finance (2004).
} 
The work of the Commission was an essential first step in the revision of Switzerland's system of supervision. It has yet to be decided whether the supervision of introducing brokers, foreign exchange negotiators, independent asset managers, audit companies, and pension funds should be held by the new authority (FINMA) and whether the other regulatory agencies should be integrated within the FINMA or not. More work has to be done in order to identify the risks generated by all types of financial institutions that are not sufficiently or insufficiently supervised, and then to find the most appropriate regulatory structure.

\section{Acknowledgements}

The author is grateful to Ms. Maude Montani, Ms. Julie Michel and Mr. Martin Walker, University of Fribourg/Switzerland, as well as to Mr. Jeremy Streatfeild, World Trade Institute, Berne/Switzerland for their invaluable contributions and comments.

\section{References}

Abrams, R.K. and Taylor, M.W. (2000) Issues in the unification of financial sector supervision, IMF working paper no. 00/213, International Monetary Fund, Washington, DC, paper presented 4 December 2003 at the World Bank Conference, Aligning Supervisory Structures with Country Needs, Washington, DC.

Beck, A., Gerber, D. and Hauser, T. (2003) 'Economic \& Policy Consulting, Quel avenir pour la prévoyance professionnelle? Crédit Suisse, Bulletin (February).

Borio, C.E.V. and Filosa, R. (1994) The changing borders of banking: Trends and implications, BIS economic paper 43 (December), Basle.

Briault, C.L. (1999) The rationale for a single national financial services regulator, occasional paper no. 2 , Financial Services Authority, London.

Buchanan, J.M. and Tollison, R.D. (1972) Theory of Public Choice: Political Applications of Economics, Ann Arbor, MI: University of Michigan Press.

Federal Department of Finance (2003) Swiss Guidelines for Financial Market Policy (August), Berne.

Federal Department of Finance (2004) Rapport du DFF concernant les résultats de la consultation sur le ler rapport partiel de la Commission d'experts "Surveillance intégrée des marches financiers", instituée par le Conseil fédéral (June), Berne.

Federal Department of Home Affairs (2003) Prévoyance professionnelle: examen de problèmes structurels, Institution de deux commissions d'experts, Communiqué de presse du 11 juillet, 2003 (www.bsv.admin.ch/ aktuell/presse/2003/f/03071101.htm).

Goodhart, C.A.E. (1995) Some regulatory concerns, special paper 79 (December), London School of Economics Financial Markets Group.

Goodhart, C.A.E., Hartmann, P., Llewellyn, D. and Rojas-Suarez, L. (1998) Financial Regulation: Why, How and Where Now?, London and New York: Routledge.

IMF (2002) Switzerland: Financial System Stability Assessment, including Reports on the Observance of Standards and Codes on the following topics: Banking Supervision, Securities Regulation, Insurance Regulation, Payment Systems, and Monetary and Financial Policy Transparency, Country Report 02(108) (www.efd.admin.ch/d/dok/berichte/2002/06/iwf_stabilitaetsbericht.pdf).

Kahn, A.E. (1971) The Economics of Regulation: Principles and Institutions, New York: Wiley and Sons.

Lubochinsky, C. (2003) Intégration financière européenne: des enjeux théoriques au plan d'action sur les services financiers, Rencontres Economiques d'Aix en Provence, Session Intégration Financière Européenne.

Martinez, J.L. and Rose, T.A. (2003) International survey of integrated financial sector supervision, World Bank Policy research paper 3096, presented to the World Bank Conference, Aligning Supervisory Structures with Country Needs, 4 December 2003, Washington, DC. 
Peltzman, S. (1976) 'Towards a more general theory of regulation', Journal of Law and Economics 19(2): 211-240.

Posner, R. (1971) 'Taxation by regulation', Bell Journal of Economics 2(1): 22-50.

Schem, C. and Lagassé, J-F. (2003) 'La gestion de fortune indépendante, un métier appelé à de grandes mutations', Le Temps, 1 September.

Stigler, G. (1971) 'The economic theory of regulation', Bell Journal of Economics 2: 3-21.

Supervision of Financial Markets Expert Group (Zufferey Commission) (2000) La réglementation et la surveillance des marchés financiers en Suisse, Final report (November), Bern (www.efd.admin.ch/f/dok/ berichte/2000/11/finanzmarkt.pdf).

Swiss Federal Banking Commission (2002) Rapport de gestion, Bern (www.ebk.ch).

Swiss Federal Banking Commission (2003) Rapport de la CFB sur les sanctions (April), Bern (www.ebk.ch).

Swiss Federal Statistical Office (2002) Statistiques des caisses de pension 2000, Neuchâtel.

Taylor, M. (1995) Twin Peaks: A Regulatory Structure for the New Century, London: Centre for the Study of Financial Innovation.

Taylor, M. and Fleming, A. (1999) Integrated Financial Supervision: Lessons of Northern European Experience, paper presented at the 4 December 2004, World Bank Conference, Aligning Supervisory Structures with Country Needs, Washington, DC.

Zimmerli Commission (2003) Surveillance intégrée des marchés financiers, 1er rapport partiel (July), Bern, (www.efd.admin.ch/f/dok/berichte/2003/07/finmag.pdf).

Zimmerli Commission (2004) Sanktionen in der Finanzmarktaufsicht, II. Teilbericht der vom Bundesrat eingesetzten Expertenkommission (August), Bern.

Zufferey, J.-B. (2003) Conférence de presse de la Commission fédérale des banques du 2 mai 2003 (www.ebk.admin.ch/f/aktuell/m030502-04f.pdf).

\section{About the author}

Philippe Gugler is Professor of Economics and Social Sciences at the University of Fribourg, Switzerland. He has also worked at the Swiss Ministry of Economics as Swiss delegate for the Uruguay Round negotiation and at the Swiss Competition Commission Secretariat as Vice-Director. He has collaborated also with several international organizations such as the United Nations (Geneva) and the OECD (Paris). He is a member of the board of several academic associations such as the European International Business Academy (EIBA). His main publications are on trade and competition, trade and investment, competition policy, multinational enterprises. 